İş ve İnsan Dergisi | The Journal of Human and Work

Y1l | Year: Ekim | October 2019

Cilt-Say1 | Volume-Issue: 6 (2)

ss I pp: 161-175

doi: $10.18394 /$ iid. 532018

e-ISSN 2148-967X

http://dergipark.gov.tr/iid/

Araştırma Makalesi

\title{
Y Kuşağı Bilgi Çalışanları: Duygusal Zeka ile Örgütsel Bağlılık İlişkisi Üzerinde Öz-Yeterliliğin Rolü
}

\author{
Generation Y Knowledge Workers: The Role of Self-Efficacy on the Relationship \\ between Emotional Intelligence and Organizational Commitment
}

\author{
Ceren Aydogmus ${ }^{\mathrm{a}}$
}

\section{MAKALE BİLGİSI}

Anahtar Kelimeler:

Duygusal Zeka, Öz-yeterlilik, Örgütsel Bağlilık

Tarihler :

Received 25 Subat 2019

Received in revised form 12

Haziran 2019

Accepted 24 Haziran 2019
ÖZ

Bu araştırma, Y Kuşağ bilgi çalışanlarının duygusal zekâları ile örgütsel bağlllıkları ilişsisi üzerinde öz-yeterlilik düzeylerinin etkisini inceleyen bir model sunmaktadır. Araștırmanın örneklemini, Ankara ilindeki üç üniversitede yer alan tekno-parklarda bulunan 37 teknoloji şirketinde görev yapan 591 Y Kuşağı bilgi çalışanı oluşturmaktadır. Araştırma verileri anket tekniği kullanılarak toplanmıştır. Araştırma değişkenlerinin ölçülmesinde Duygusal Zekâ, Özyeterlilik ve Örgütsel Bağlllık ölçekleri kullanılmıştır. Ölçeklerin geçerlilikleri doğrulayıcı faktör analizi ile test edilmiştir. Değişkenler arasındaki ilişkiyi belirlemek için korelasyon analizi, aracılık rolünü tespit etmek için ise yapısal essitlik modellemesinden yararlanılmıștır. Elde edilen bulgular Y Kuşağı bilgi çalışanlarının duygusal zekâlarının öz-yeterlilik ve örgütsel bağlllıklarını olumlu yönde etkilediğini göstermektedir. Y Kuşağl bilgi çalışanlarının özyeterlilikleri ile örgütsel bağglllkları arasında olumlu ve anlaml bir ilişki tespit edilmiştir. Sonuç olarak, Y Kuşağı bilgi çalıșanlarının duygusal zekâlarının örgütsel bağlllıkları üzerindeki etkisinde öz-yeterlilik düzeylerinin tam aracıllk etkisine sahip olduğu belirlenmiştir.

\section{ARTICLE INFO}

\section{Keywords:}

Emotional Intelligence, Self-

Efficacy, Organizational

Commitment

Article history:

Geliş 25 February 2019

Düzeltme geliș 12 June 2019

Kabul 24 June 2019

\begin{abstract}
A B S T R ACT
This study proposed a model for the impact of Generation Y knowledge workers' self-efficacy levels on the relationship between their emotional intelligence and organizational commitment. The model was tested on a sample of 591 Generation Y knowledge workers working in 37 Information Technology companies in the techno-parks of three universities in Ankara. Survey methodology was used to collect data. Emotional Intelligence, Self-Efficacy and Affective Commitment scales were used for measuring the study variables. Confirmatory factor analysis was used to test the validity of the scales. Correlation analysis was used in order to measure the relationships among the study variables and structural equation modelling was conducted to test the proposed mediating effect. Findings reveal that Generation $Y$ knowledge workers' emotional intelligence positively influence their self-efficacy and organizational commitment. There exists a positive relationship between Generation Y knowledge workers' self-efficacy and organizational commitment. Consequently, Generation $Y$ knowledge workers' self-efficacy levels have been found to act as a mediator between their emotional intelligence and organizational commitment.
\end{abstract}

\footnotetext{
a İletişim kurulacak yazar, Bilkent Üniversitesi, İşletme Fakültesi, İşletme Bölümü, Ankara, Türkiye. E-mail: caydogmus@bilkent.edu.tr. ORCID: 0000-0002-2982-2011
} 


\section{GİRIŞ}

Günümüzde globalleşme, rekabet şartları ve yönetim paradigmaları örgütlerde sürekli olarak bir değişim gerektirmektedir. $\mathrm{Bu}$ değişim içerisinde örgütün varlığını devam ettirebilmesi ve başarılı olabilmesi için gerekli olan en kritik işletme varlığ ise örgütte çalışanlardır (Ergeneli, 2006: 113). Bu bağlamda yöneticilerin çalışanlarla olan ilişkilerine dikkat etmesi ve gerektiğinde yeniden yapılandırması çağımızın örgütleri için zorunluluk haline gelmiştir. Çalışanlar, örgüte ne kadar bağlıysa, örgüt de o derecede güçlenmektedir. Teknolojik ilerlemelerin 1şığı altında, günümüz örgütlerinin, içinde bulundukları global rekabet ortamında var olabilmek adına her zamankinden çok çalışanlarının örgüte olan bağlılığ üzerinde odaklanmaları gerekmektedir. $\mathrm{Bu}$ açıdan örgütlerin dikkate almaları gereken en önemli noktalardan biri çalışanın örgüte karşı hissettiği bağl1lık duygusunun ifadesi olan örgütsel bağlılığın (Bayram, 2005: 126) kuşaklar açısından da irdelenmesidir. Kuşak, aynı zaman aralığı içinde doğmuş, aynı çağın koşullarında yaşamış, birbirine benzer özellikleri, tercihleri, değer yargıları, amaçları ve tutumları olan kişilerin oluşturduğu topluluğa verilen addır (Lower, 2008: 80). Son yıllarda farklı kuşaklardaki çalışanların iş performansı, psikolojik olarak güçlendirme algısı, liderlik stili tercihleri, iş tatmini ve örgütsel bağlılığı gibi konular yöneticilerin, insan kaynakları uzmanlarının ve araştırmacıların ilgi odağı haline gelmiştir (Aydogmus, Camgöz, Ergeneli \& Ekmekçi, 2018; Ng, Schweitzer \& Lyons, 2010). Günümüzde kuşaklararası değerlendirmeye bakıldığında 1980-1999 yılları arasında doğmuş olan kişilerin oluşturduğu ve Milenyum, Dijital Kuşak veya Internet kuşağ olarak da adlandırılan Y Kuşağı, dünyadaki toplam 7 milyar nüfusun 1.8 milyarını oluşturarak dünyadaki en geniş nesil olarak tanımlanmaktadır. Şu anda Türkiye nüfusunun yaklaşık olarak yarısını kapsamakta olan Y Kuşağı'nın 2025 y1lı itibariyle dünya çalışan nüfusunun $\% 75$ 'ini oluşturması beklenmektedir (Deloitte, 2017: 5).

Teknolojik becerisi yüksek, fiziksel emeğinden ziyade zihinsel emeği ile içinde çalıştı̆̆ katkı sağlayan ve üst düzeyde eğitime sahip olan çalışanları ifade etmek için kullanılan bir kavram olan bilgi çalışanları ise günümüzde örgütlerin globalleşme, artan rekabet ve gelişen teknoloji karşısında büyümeleri ve lider konuma gelebilmelerinde etkili olan en kritik kaynaklardan biri olarak değerlendirilmektedir (Drucker, 1999: 81). Örgütlerine aynı zamanda stratejik bir rekabet avantajı sağlayan bu nitelikli grubun örgütsel bağlılıklarının arttırılması günümüz araştırmalarında önemli bir konu haline gelmiştir.
Ancak bugüne kadar yapılan çalışmalara bakıldığında özellikle Türkiye'de Y Kuşağı bilgi çalışanlarının örgütsel bağl1lıkları üzerinde etkili olan faktörleri inceleyen çok fazla araştırma bulunmadığı görülmüştür. Bu nedenle, bu çalışmada örneklem grubu olarak Y Kuşağı bilgi çalışanları seçilmiştir.

Çalışanların örgütsel bağlılığı üzerinde etkili olan faktörlerden birinin duygusal zekâ olduğu tespit edilmiştir (Naderi, 2012: 257). Duyguların örgüt yaşamının ayrılmaz bir parçası olduğu, ve çalışanların mutluluğunun sağlanabilmesinde, belirli bir entellektüel zekâ düzeyi kadar, duygusal zekâya da sahip olmaları gerektiği pek çok araştırmada vurgulanmaktadır (Ashforth \& Humphrey, 1995; Aydogmus, 2016). Yüksek duygusal zekânın çalışanların örgütsel bağlılıkları üzerindeki olumlu etkisi gerek ulusal, gerekse de uluslararası yazında çeşitli araştırmalarda tespit edilmiştir (Aghdasi, Kiamanesh \& Ebrahim, 2011; Arslan, Dilek \& Aydın, 2013).

Duygusal zekânın etkilediği diğer bir faktör ise özyeterlilik algısıdır (Chan, 2004: 1782). Özyeterlilik, çalışanların, bireysel yaşamlarını etkileyebilecek olaylar üzerinde kontrol sahibi olmalarını sağlayan yeteneklerine olan inançlarıdır (Bandura, 1997). Öz-yeterlilik kişinin duygusal zekâsından olumlu ve anlamlı bir şekilde etkilenmektedir. Duygusal zekânın yüksek olması duygularda farkındalık ve duygu kontrolü sağlar. Duygularını anlayabilen ve kontrol edebilen kişinin öz-yeterlilik duygusu da yüksek olacaktır (Chan, 2004: 1783). Sosyal Bilişsel Kuram'a göre, kişiler yaşadıkları başarılı deneyimler neticesinde genellenebilir ve kararlılık gösteren bir yetkinlik algısı geliştirmektedirler (Bandura, 1997). Sahip olduğu yetkinlik inancı sayesinde olumlu değerlendirmelerde bulunabilen kişi, zor durumlarla etkili bir şekilde baş edebilme ve karşılaştığ 1 stresli durumlara kararlı bir şekilde tepki verebilmektedir. Neticede öz-yeterlilik algısı ile başarılı bir biçimde tamamlanmış herhangi bir performans, bu alanla ilişkili olan diğer alanlara da genellenebilmektedir. Alanyazında çalışanın öz-yeterlilik algısının performans (Heslin \& Latham, 2004: 23), iş tatmini (Baggerly \& Osborn, 2006: 197), liderlik (Paglis \& Green, 2002: 215) gibi pek çok örgütsel değişkeni etkilediğine dair araştırmalar mevcuttur. Özyeterlilik algısının örgütsel bağlılığı da olumlu bir şekilde etkilediği uluslararası yazındaki çeşitli araştırmalarda saptanmıştır (Agarwal \& Mishra, 2016; Sinha, Talwar \& Rajpal, 2002). Ancak bu konuda ulusal yazında yapılmış çok fazla araştırmaya rastlanmamıştır (Ayık, Savaş \& Yücel, 2015). Bunun yanı sıra, Y Kuşağı bilgi çalışanlarının duygusal zekâlarının örgüte olan bağlılıklarını hangi mekanizma vasıtasıyla 
etkilediğine ilişkin de alanyazında herhangi bir araştırmaya rastlanmamıştır. Alanyazında bu konudaki eksikliği gidermek amacıyla bu çalışmada, ülkemizdeki Y Kuşağı bilgi çalışanlarının duygusal zekâ seviyelerinin örgütlerine olan bağlılıkları üzerindeki etkisi araştırılmıştır. Çalışmada Y kuşak bilgi çalışanlarının öz-yeterlilik algıları, duygusal zekâ ile örgüte olan bağlılıkları arasında aracı olarak incelenmiştir.

Çalışmanın bir sonraki bölümünde ilk olarak çalışmanın gerçekleştirildiği örneklem grubunun özellikleri açıklanmış, daha sonra duygusal zekâ, öz-yeterlilik ve örgüte olan bağlılığa ilişkin kavramsal çerçeveye değinilmiş ve çalışmanın araștırma hipotezleri sunulmuştur. Bundan sonraki bölümlerde ise sırasıyla yöntem, bulgular, sonuç ve tartışma kısımları yer almıştır.

\section{KAVRAMSAL CCERÇEVE}

\subsection{Y Kuşağı Bilgi Çalışanları}

Y Kuşağı'nda bulunan kişilerin en belirgin özellikleri teknolojik gelişmelerin en fazla düzeyde olduğu bir çağda doğduklarından dolayı teknolojiye olan yatkınlıklarıdır. Dolayısıyla bu kuşak 21 . Yüzyılda yaşanan teknolojik gelişmelere hızlı bir şekilde ayak uyduran, yenilikleri ve farklılıkları seven bir nesil olarak karşımıza çıkmaktadır (Lowe, Levitt \& Wilson, 2008: 46).

Y Kuşağı kendinden önceki Baby Boomer (19461964) ve $X$ Kuşağı (1965-1979) ile karşılaştırıldığında daha zor yönetilebilmektedir. Kuşaklararası farklılığın en çok hissedildiği nesil olan Y Kuşağı, bağımsızlığına ve özgürlüğüne önem veren, belirlenen çalışma saatleri arasında çalışmaktan çok hoşlanmayan, iş saatinden çok yaptığı işe odaklanan ve işin bir parçası olmaktan keyif alan kişilerden oluşmaktadır. Bu kuşak için yerine getirdiği iş ve görevlerin dünyada olumlu bir değişime katkıda bulunmasını görmek son derece önemlidir (Behrstock-Sherratt \& Coggshall, 2010: 30). Y Kuşağı, iş dünyası ve toplumu ilgilendiren pek çok konuda kendini sorumlu hissederek, çalıştığı örgütün toplumda iz bırakması gerektiğine inanmaktadır (Deloitte, 2017).

Y Kuşağı çalışanlarının aynı anda birden fazla konu ile ilgilenebilme yetenekleri mevcuttur ve iyi yönetildiklerinde örgüt açısından zengin bir yetenek kaynağı haline gelmektedirler (Lowe vd., 2008: 47). Yöneticiler açısından çalışanlarının duygularını yönetebilmek önemli bir husustur. Bu açıdan diğer kuşaklardan oldukça farklı özellikler taşıyan Y Kuşağı çalışanlarının duygusal zekâları, örgütlerin özellikle dikkate alması gereken hususlardan biridir (Aydogmus, 2016: 1345).

Otoriteden çok haz almayan Y Kuşağı, kendisine karşı kesin ve net kuralların konulmasından hoşlanmaz. Bazı araştırmacılar (Brown, Thomas \& Bosselman, 2015; Twenge, 2007), Y Kuşağ1 çalışanlarının önceki kuşaklar ile karşılaştırıldığında, çok daha fazla iş değiştirdiklerini ifade etmiştir. Deloitte (2017) tarafindan yapılan "Y Kuşağı Araştırması", başta Avrupa, Ortadoğu ve Afrika bölgeleri olmak üzere dünyanın farklı yerlerinde meydan gelen saldırıların, politik gerginliklerin ve ekonomik belirsizliklerin, Y Kuşağı'nın güveninin sarsılmasına neden olduğunu belirlemiştir. Elde edilen bulgular, ișten ayrılmayı düşünme oranlarındaki yüksekliğe dikkat çekmektedir; Türkiye'nin de aralarında bulunduğu 30 ülkede 8000 Y Kuşağı çalışanının katılımıyla gerçekleştirilen araştırmada (Deloitte, 2017), Y Kuşağı çalışanlarından, mevcut iş yerlerinden 2 yıl içerisinde ayrılabileceğini düşünenlerin oranı Türkiye'de $\% 46$, globalde ise $\% 38$ olarak tespit edilmiştir. Çalışan, örgüt değerlerine bağlı olduğunda ve bu değerlerin gerçekleştirilmesine katkıda bulunmak istediğinde, işten de ayrılmak istemeyecektir (Meyer, Stanley, Herscovitch \& Topolnytsky, 2002: 25). Araştırmalar, örgütsel bağlılığın, iş tatminine oranla işten ayrılmanın daha iyi bir göstergesi olduğunu göstermektedir (Meyer \& Allen, 1991; Patalano, 2008). Bu açıdan, Y Kuşağı çalışanlarının örgütsel bağl1lıkları yöneticiler için dikkatle yaklaşılması gereken bir unsurdur (Patalano, 2008).

Örgütsel bağlılıkları geleneksel çalışanlardan büyük ölçüde farklılaşan bilgi çalışanları ise inovasyon, araştırma ve geliştirme gibi bilgi üretiminin yoğun olduğu sektörlerde çalışmaktadır (Drucker, 1999: 82). Bu çalıșmada örneklem grubu olarak Y kuşak bilgi çalışanlarının seçilmesinin nedenleri bu kuşak çalışanlarının teknolojiye olan yatkınlıkları, aynı anda birden fazla iş yapabilmedeki becerileri, teknolojik gelişmelere ayak uydurabilmeleri, inovasyon ve farklılıklara karşı açık olmaları gibi özellikleridir.

\subsection{Duygusal Zekâ}

Duygusal zekânın teorik alt yapısı Thorndike'in (1920) geliştirmiş olduğu Sosyal Zeka Modeli ile oluşmuş olsa da, duygusal zekâ, esas olarak, kullanılan standart zekâ (IQ) testleri gibi genel ölçüm testlerinden başarılı çıkan çalışanların pek çoğunun iş hayatında başarısız olduklarının tespit edilmesiyle araştırmaya başlanmıştır. Duygusal zekâ kişinin kendisi ile çevresindekilerle olan ilişkisinin temelini oluşturmaktadır (Goleman, 
1995). Cooper ve Sawaf (1997: 12) duygusal zekây1 "duyguların gücünü ve hızlı algılayışını, insan enerjisi, bilgisi, ilişkileri ve etkisinin bir kaynağ 1 olarak duyumsama, anlama ve etkin bir biçimde kullanma yeteneği" olarak ifade etmiştir. Öte yandan Bar-On (2006: 13) duygusal zekânın kişisel, duygusal ve sosyal faktörler gibi bilişsel olmayan zekâ unsurlarını da kapsadığını vurgulamıştır. Tüm bu zekâ faktörlerinin ortak özelliği kişinin hayattaki zor ve problemli durumlarla başa çıkabilmesi açısından bilişsel zekâdan daha etkili olmalarıdır. Bar-On'a (2006) göre duygusal zekâ, kişinin kendinin farkında olması gibi hem zihinsel yeteneklerinin, hem de kişisel bağımsızlık, kendine sayg1 gibi zihinsel yeteneklerden farklı olarak değerlendirilen özelliklerinin bir bütünüdür.

Salovey ve Mayer (1990) ise, başkalarının duygularını ve hislerini anlama becerisi olarak tanımladıkları duygusal zekâyı tek bir yetenek olarak değil, duygusal muhakeme yeteneğinin, duyguları anlama ve kontrol edebilme özelliğinin bir bileşimi olarak ifade etmişlerdir. Salovey ve Mayer'ın "duygusal zekâ" tanımından yola çıkarak Wong ve Law (2002: 246) duygusal zekây1: (1) bireyin kendi hislerini anlama ve farkında olmasını ifade eden özbilinç; (2) bireyin çevresindeki kişilerin duygularını anlayabilmesini içeren empati; (3) bireyin duygularını doğru ve olumlu bir şekilde kullanmasını ifade eden duygu kullanımı; ve (4) bireyin duygularını kontrol edebilmesi ve düzenleyebilmesini içeren duygu yönetimi olarak dört ana grupta incelemişlerdir.

Goleman (1995) iyimserliğin duygusal zekânın önemli özelliklerinden biri olduğunu belirterek, iyimserliğin getirdiği iş yerinde olumlu düşünce gücünün pek çok örgütsel davranış değişkeni üzerinde etkisi olduğunu vurgulamıştır. Goleman'a (1995) göre yüksek duygusal zekâ seviyesi tatminkarlığı, yüksek morali, yüksek beklenti ve olumlu amaç sahibi olmayı etkilemektedir.

Duygusal zekâ iş tatminini (Aydogmus, 2016: 1342), performans1 (O'Boyle, Humphrey, Pollack, Hawver \& Story, 2011: 788), örgütsel vatandaşlık davranışını (Korkmaz \& Arpacı, 2009: 2432) ve örgütsel bağlılığı (Aghdasi vd., 2011: 1965) olumlu olarak etkilemektedir. Tüm bu değerlendirmeler doğrultusunda duygusal zekâ, çalışma ortamını anlayabilmek ve duyguları etkin bir şekilde kullanabilmek açısından son derece etkilidir. Araştırmacılar duygusal zekânın her yaşta geliştirilebileceğini belirtmektedir (Acar, 2002: 55).

\section{3. Öz-yeterlilik}

Bandura'nın (1988) Sosyal Öğrenme Kuramı'nın temel kavramlarından biri olan öz-yeterlilik, kişinin yaşamını etkileyen olaylar karşısında kendisinden beklenen performansı sergileyebilmesi için kendi yeteneklerine olan inancidır (Bandura, 1997). Uysal ve Kösemen (2013: 218) öz-yeterlilik algısının kişinin zor durumlarla karşılaştığında ortaya koyduğu mücadele gücü olduğunu ifade etmiştir. Çalışanların, yeterlilik beklentilerine ilişkin algıları, iş hayatında eyleme geçmelerini ve sorunlarla mücadele azimlerini olumlu olarak etkilemektedir. Öz-yeterlilik, kişinin becerilerinin bir fonksiyonu değil, kişinin becerisini kullanarak yapabileceklerine ilişkin yargılarının bir sonucudur. Bandura (1997) öz-yeterlilik algısının çalışanın kendisine zor, ama aynı zamanda gerçekçi hedefler seçmesini sağlayarak, seçilen hedeflere bağlılık göstermesi yoluyla, iş performansını olumlu şekilde etkilediğini vurgulamıştır. Çalışanın öz-yeterlilik algısı sadece iş performansı gibi bireysel çıktılar ile ilgili bir kavram olmanın ötesinde, örgütsel çıktılarla da ilgili bir kavramadır. Öz-yeterlilik algısını örgütsel anlamda ilk inceleyen araştırmacılardan olan Staples, Hulland ve Higgins (1999: 760), öz-yeterliliğin iş tatmini ve örgütsel bağlılık gibi örgütsel değişkenlerle olan olumlu iliş̧isine dikkat çekmiştir. Çalışanın öz-yeterlilik algısını doğru ve etkin bir şekilde yönlendirmesi ile arzu edilen örgütsel çıktıların sağlanması da mümkün olmaktadır. Öz-yeterlilik algısı, bireysel hedefler, tepkiler ve analitik stratejileri kullanma performansını arttırarak, olumlu örgütsel çıktıların sağlanmasında etkili olmaktadır. Öz-yeterlilik algısı kişinin başarısını ve tutumunu olumlu olarak etkilediği gibi, yeni fikirlere açık olunmasında da etkendir (Bandura, 1997).

\section{4. Örgütsel Băglılık}

Ergeneli (2006: 113), örgütsel bağlılığı, işgörenin örgütün ve işinin özelliklerini değerlendirmesi ile örgüte karş1 gösterdiği tutum ve neticede sergilediği olumlu davranışların göstergesi olarak ifade etmiştir. O’Reilly ve Chatman'a (1986: 493) göre örgütsel bağlılık bireysel amaçlara ulaşmayı kapsayan uyum boyutu, örgütteki diğer çalışanlara yakın olma duygusunu içeren özdeşleşme boyutu ile kişisel ve örgütsel amaç ve değerlerin uygunluğunu ifade eden içselleştirme boyutlarının tümünü betimlemektedir.

Örgütsel bağlılığın artmasının iş tatmini, iş performansı, örgütsel vatandaşlık davranışı ve işten ayrılma niyetinde azalma şeklinde pek çok olumlu etkisi bulunmaktadır (Meyer vd., 2002: 21). Tüm bu olumlu çıktılardan dolayı, alanyazında örgütsel bağlılığı arttırıcı mekanizmaların incelenmesi araştırmacıların ilgisini çekmektedir. Örgütsel bağlılığın, alanyazında davranışsal ve tutumsal olarak ele alındığı görülmektedir. Davranışsal bağlılık, çalışanın geçmiş deneyimleri ve örgüte 
uyum sağlamasına göre oluşan örgüte bağlı hale gelme süreci ile ilişkilidir. Davranışsal bağlılık, örgütten daha çok, çalışanın davranışlarına göre şekillenmektedir (Meyer \& Allen, 1991: 63). Tutumsal bağlılık ise, çalışanın, kendisini, örgüt ve örgütün amaçlarıyla tanımladığı ve bu amaçlara ulaşılmasına yardımcı olma isteği duymasını ifade eder (Mowday, Steers \& Porter, 1979: 226). Bu bağlamda Baysal ve Paksoy (1999: 7), örgütsel bağlılığı "işgörenin çalıştığı örgüt ile özdeşleşerek, örgütün ilke, amaç ve değerlerini benimsemesinin, örgütsel kazançlar için çaba göstermesinin ve örgütte çalışmayı sürdürme isteğinin ölçüsü” olarak ifade etmiştir. Meyer ve Allen (1991: 73) ise örgütsel bağlılığı, çalışanların örgütle ilişkisi ile şekillenen ve örgütün sürekli üyesi olma kararını almalarını sağlayan davranış olarak tanımlayarak, örgütsel bağlılığın psikolojik bir içeriğe sahip olduğunu belirtmişlerdir. Örgütsel bağlılık, çalışanın, örgütte gerçekleştirdiği zaman ve çaba gibi yatırımlarının sonucunda gelişen devamlı bağlılık, çalışanın, örgütte çalışmayı kendisi için bir görev olarak görmesi ile oluşan normatif bağlılık, ile çalışanın, örgüt değerlerini, hedeflerini ve amaçlarını benimsediği oranda hissettiği duygusal bağlılık olarak üç ana grupta incelenmiştir (Meyer \& Allen, 1991: 69-72).

\subsection{Araștırma Değişkenleri Arasındaki İlișkiler}

Araştırma değişkenleri arasındaki ilişkiler Bandura'nın Sosyal Öğrenme Kuramı'na dayanmaktadır. Bandura'nın (1997) ifade ettiği gibi Sosyal Öğrenme Kuramı'nda, başarılı bir biçimde tamamlanmış herhangi bir performans, bu alanla ilişkili olan diğer alanlara da genellenebilmektedir. $\mathrm{Bu}$ kuramdan yola çıkarak, Y Kuşağı bilgi çalışanının duygusal zekâ seviyesi yükseldiğinde, öz-yeterlilik algısının da artması ve buna bağlı olarak örgütsel bağlılık hissinin de yükselmesi beklenmektedir.

2.5.1. Duygusal Zeka ve Örgütsel Bağlılı İlişkisi. Örgütsel bağlılığ 1 arttıran unsurlar arasında çalışanın kişisel özellikleri, iş yaşantısı, işin özelliği ve çalışma deneyimi gibi bireysel ve örgütsel faktörler bulunmaktadır (Chi, Yeh \& Choum, 2013; Ergeneli, 2006). Son yıllarda duygusal zekâ da örgütsel bağlılığın artmasında etkili olan bir unsur olarak ele alınmıştır (Aghdasi vd., 2011; Arslan vd., 2013).

Örgütsel bağlılık, çalışanın işi ile ilgili olumlu değerlemelerine karşı verdiği duygusal tepkidir (Testa, 2001: 227). Özellikle kişisel duyguları değerleme yeteneği yüksek olan çalışanlar, duygularının, beceri ve yeteneklerinin farkında ve kendine güvenen kişilerdir. Empati yeteneği yüksek olan bir çalışan, çevresi ile sağlıklı iletişim kurabilmekte, duygu kullanımı ve yönetimi yeteneği sayesinde, örgütte karşılaştığı çeşitli sorunları çözebilme yeterliliğine sahip olarak duygularını akıllıca kontrol edebilmektedir (Arslan vd., 2013: 171). Wong ve Law (2002: 248), duygusal zekâsı yüksek olan çalışanların, örgütsel bağlılıklarının da yüksek olduğunu ifade etmiştir. Abraham (1999: 443) ise duygularının farkında olmayarak duygularını yönetemeyen çalışanların örgütsel bağlılıklarının düşük olduğunu belirtmiştir. Nikolaou ve Tsaousis (2002: 327), duygusal zekânın özbilinç, empati, duygu kullanımı ve yönetimi boyutları ile örgütsel bağlılık arasında olumlu ilişki saptamıştır. Carmeli (2003) ise yüksek duygusal zekâya sahip olan çalışanların örgütlerine olan adanmışlık hissinin yükseldiğini belirlemiştir.

Çalışanların demografik özelliklerini örgütsel bağlılık açısından ele alan araştırmalar (Iqbal, 2010; Özkaya, Kocakoç \& Karaa, 2006) bulunsa da, Y Kuşağı bilgi çalışanlarının duygusal zekâsı ile örgütsel bağlılıkları arasındaki ilişkiyi inceleyen herhangi bir araştırmaya rastlanmamıştır. Alanyazındaki bu boşluğu giderebilmek amacıyla, bu araştırmada, aşağıdaki hipotez önerilmiștir:

Hipotez 1: Y Kuşağı bilgi çalışanlarının duygusal zekâları örgütsel bağlılıklarını olumlu yönde etkilemektedir.

2.5.2. Duygusal Zeka ve Öz-yeterlilik İlişkisi. Özyeterlilik algısının oluşumunda, kişilerin duygusal zekâlarının olumlu etkisi çeşitli araştırmalarda ele alınmıştır (Kaufhold \& Johnson, 2005; Şenel, Adiloğulları \& Ulucan, 2014). Sosyal Öğrenme Kuramı'na göre kişilerin sahip oldukları becerileri etkin şekilde kullanabilmelerinde en önemli etken, ilgili alanda, öz güven hissi duyulmasıdır. Duygusal zekâsı yüksek olan birey, güçlü yanlarının ve sınırlarının bilincinde ve öz güven sahibidir (Goleman, 2014). Fabio ve Palazzeschi (2008: 315), araştırmalarında, kişilerin öz-yeterlilikleri üzerinde en fazla etkili olan duygusal zekâ boyutlarını, çevresel duyguları değerleme, diğer bir deyişle empati ve duygu yönetimi olarak belirlemişlerdir. Bunun yanı sıra, daha genç çalışanların duygusal zekâ seviyelerinin, kendilerinden yaşça büyük olan çalıșanlara kıyasla daha fazla olduğu da belirtilmiştir. Genç çalışanların, özellikle çevre ile iletişimde etkili olan empati ve duygularını kullanabilme yetenekleri, bu çalışanların baskı halinde duygularını kontrol edebilmelerini ve problemlerin etkili bir şekilde üstesinden gelebilmelerini sağlamaktadır (Fabio \& Palazzeschi, 2008: 318).

Kaufhold ve Johnson'a (2005: 615) göre duygusal zekâ seviyeleri yüksek olan çalışanlar, bireysel farklıl1kların daha fazla bilincinde olarak, grup 
çalışması ve problem çözme becerileri geliştirerek, örgütte sosyal becerilerin de artmasına katkıda bulunmaktadır. Chan (2004: 1781) duygusal zekâ seviyeleri düşük olan çalışanların, öz-yeterlilik duygularının da düşük seviyede olduğunu saptamıştır. Duygusal zekâ, öz-yeterlilik duygusunu arttırarak, çalışanların olumlu bir tutum içerisinde, ilişkileri daha iyi yönetebilmelerine yardımcı olmakta, duyguların etkin bir şekilde kullanımı sayesinde de problemlere doğru çözüm stratejileri getirilmesini kolaylaştırmaktadır.

Bandura'ya (1997) göre kişilerin öz-yeterliliği başlıca dört kaynaktan aldıkları bilgilerle şekillenmektedir. $\mathrm{Bu}$ kaynaklardan ilki, kişinin geçmiş deneyimlerinden edindiği sonuçlardır. Özbilincin yüksek olması, kişinin farkındalığının ve bireysel olarak kendini değerlendirme yeteneğinin gelişmiş olmasını ifade etmektedir. İkinci olarak, kişiler, çevresindekilerinin davranışlarını gözlemleyerek öz-yeterlilik inançları geliştirirler. Çevresel duyguları değerleme yeteneğinin yüksek olması, başkalarının davranışlarını anlayabilme, bu davranışlara karşı empati geliştirme ve çevre ile uyumlu olmayı içermektedir. Öz-yeterliliğin gelişmesinde etkili olan üçüncü kaynak ise, kişilerin çevresinde gördükleri sosyal baskılar karşısında özyeterlilik algılarının şekillenmesidir. Kişinin duygularını kullanarak kontrol edebilmesi, çevresindeki baskı ve problemlere karşı etkin bir şekilde tepki verebilmesini sağlar. Son olarak, kişilerin duygusal durumları, öz-yeterlilik algısının gelişiminde etkilidir. Duygularını yönetebilen kişiler, duygusal zekâları sayesinde gerilim ve kaygı gibi duygulanım durumlarının üstesinden daha rahat gelirler ve neticede öz-yeterlilik algıları olumlu olarak şekillenir (Bandura, 1997; Goleman, 1995). Dolayısıyla, duygusal zekânın öz-yeterliliği olumlu olarak etkilemesi beklenmektedir.

Y Kuşağı çalışanları, kendinden önceki kuşaklarla karşılaştırıldığında yeniliklere daha yatkın, hedef odaklı ve değişimlere daha kolay adapte olurlar (Brown vd., 2015: 132). Aydogmus (2016: 1349), Y Kuşağı çalışanlarının duygusal zekâ seviyelerinin ortalamanın üstünde olduğunu belirlemiştir. Keleş (2014: 95) ise teknolojiyi çok etkin bir şekilde kullanabilen Y Kuşağı çalışanlarının öz-yeterlilik algılarının yüksek olduğunu tespit etmiştir. Bu kapsamda, aşağıdaki araştırma hipotezi önerilmiştir:

Hipotez 2: Y Kuşağı bilgi çalışanlarının duygusal zekâları öz-yeterlilik inançlarını olumlu yönde etkilemektedir.

2.5.3. Öz-yeterlilik ve Örgütsel Bă̆lılık İlişkisi. Çalışanların öz-yeterlilik algısının örgütsel bağlılıklarını olumlu şekilde etkilediğine dair alanyazında pek çok araştırma mevcuttur (Agarwal
\& Mishra, 2016; Ayık vd., 2015; Sinha vd., 2002). Schwarzer'e (1994: 162) göre yüksek öz-yeterlilik, iş ortamında stresli durumlarla etkili olarak başa çıkmayı sağlamaktadır. Öz-yeterlilik, kişinin ne tür zorlukların üstesinden geleceğine karar vermesini ve hedefinin yüksek olmasını etkilemekte, dolayısıyla yüksek öz-yeterliliğe sahip olan bir kişi, iddialı ve zorlu hedefler seçmektedir. Bu bağlamda öz-yeterlilik, kişinin hedef belirlemesinde etkili olmanın yanı sıra, hedef ve amaçlarını sürdürmede ısrarcı olmasında da etkili bir faktördür (Ayık vd., 2015: 196). Benzer şekilde Ünal-Keskin ve Orgun (2006: 94), öz-yeterliliği yüksek olan kişilerin daha riskli görevleri seçtiklerini, hedeflerinin yüksek olduğunu ve bu hedeflere ulaşırken azimle çalıştıklarını belirtmişlerdir. Ayık vd. (2015: 206) ise eğitim sektöründe çalışanların öz-yeterlilik inançlarının artmasının, örgüte karşı olumlu duygular beslenmesini sağlayarak örgütsel bağlılıklarını arttırdığını tespit etmiştir. Örgütsel bağl1lık, örgütün amaçlarına inanma ve örgüt için çaba göstermeye istekli olmayı ifade etmektedir (Meyer \& Allen, 1991: 73). Öz-yeterliliği yüksek olan bir çalışan, aynı zamanda örgütün başarılı olması için de beklentilerin üstünde çaba harcayacaktır. Dolayısıyla örgütün hedeflerine ulaşmasında, çalışanın gösterdiği ilgiyi içeren örgütsel bağlılık duygusu da etkili olacaktır (Karcıoğlu ve Çelik, 2012: 3). Öz-yeterlilik gerek öğrenme sürecinde, gerekse de çalışan motivasyonunda önemli bir faktördür. Salas ve Cannon-Bowers (2001: 473) öz-yeterliliğin çalışanın yaptığı işi daha iyi öğrenmesine ve dolayısıyla daha yüksek iş performansı göstermesine neden olduğu ve çalışanın örgütsel bağlılığını arttırdığını ifade etmişlerdir. Yüksek özyeterliliğe sahip olan eğitimcilerin zorlu işleri, kendilerini işe adama ve bağlılık duygusu ile daha rahat bir şekilde tamamladıkları görülmüştür. Chi ve diğerleri (2013: 133) ise öz-yeterliliğin, örgütsel bağlılığı belirleyen ana faktör olduğunu vurgulamıştır. Sosyal bilişsel bir niteliğe sahip olan öz-yeterlilik algısı, kişinin örgütsel görev ve sorumluluklara karşı olan davranışını etkiler. Yüksek öz-yeterliliğe sahip çalışanların, düşük özyeterlilik algısı olan çalışanlara göre daha fazla çaba harcayarak, örgütsel görev ve sorumlulukların yerine getirilmesinde daha fazla bağlllık hissettikleri belirlenmiştir (Fabio \& Palazzeschi, 2008: 320).

Sahertian ve Soetjipto (2011: 50) öz-yeterliliğin, sosyal ve örgütsel çerçevede çalışanın kişisel inançlarını şekillendirdiğini, örgüt işlerinde güçlü kişisel inançların, çalışan motivasyonunu ve iş performansını arttırdığını ve çalışanın örgütsel bağlılığının da yükseldiğini belirtmişlerdir. 
Bandura (1997) çalışanların eğitim seviyelerinin özyeterlilik algısı üzerinde etkili olduğunu vurgulamıştır. Benzer şekilde Martocchio ve Judge (1997: 765), eğitimin belirli birtakım becerilerin gelişmesinde ve profesyonel bir kimlik oluşmasında etkili olduğunu, dolayısıyla kişinin kendine olan güvenini arttırarak, öz-yeterlilik algısının da yükselmesini sağladığını ifade etmişılerdir. $\mathrm{Bu}$ açıdan, bilgi çalışanlarının öz-yeterlilik algılarının yüksek olması beklenmektedir. Eğitimin aynı zamanda örgütsel bağlılık üzerinde de etkili olduğu çeşitli araştırmalarda vurgulanmıştır. Irshad ve Naz'ın (2011: 38) yapmış oldukları çalıșmada yüksek eğitim seviyesine sahip olan çalışanların örgütsel bağlılıkları da yüksek olarak tespit edilmiştir. Iqbal (2010: 16) ise düşük eğitim seviyesine sahip olan çalışanlarda, örgütsel bağlılığın da düşük olduğunu saptamıştır. Çalışmada öz-yeterlilik ve örgütsel bağlılık ilişkisi Y Kuşağı bilgi çalışanları açısından değerlendirilmiş ve bu kapsamda aşağıdaki araştırma hipotezi önerilmiştir:

Hipotez 3: Y Kuşağı bilgi çalışanlarının özyeterlilik inançları örgütsel bağl1lıklarını olumlu yönde etkilemektedir.

2.5.4. Duygusal Zeka, Öz-yeterlilik ve Örgütsel Bağlılık Ilişkileri. Y Kuşağı'nın en belirgin özelliklerinden biri kendilerine olan güvenleridir. Kendine güven, öz-yeterlilik algısında etkili olan en önemli faktörlerden biridir. Y Kuşağı çalışanları, takım çalışması ve iş arkadaşları ile uyumlu çalışma konusunda başarılı, yeniliklere açık, yaratıcı düşünen, örgütte bir fark yaratmak için çabalayan ve harcadıkları emeğe değer bir iş çıkarmak için uğraşan kişilerdir (Controls, 2010). Bu açıdan Y Kuşağı çalışanlarının öz-yeterlilik algılarının da yüksek olması beklenmektedir.

Yukarıda açıklanan sebeplerden yola çıkarak, Y Kuşağı bilgi çalışanlarının duygusal zekâlarının özyeterlilik inançlarını olumlu bir şekilde etkilemesi yoluyla, örgütsel bağlılıklarını arttıracağı beklenmektedir. Bu kapsamda aşağıdaki araştırma hipotezi önerilmiştir:

Hipotez 4: Y Kuşağı bilgi çalışanlarının duygusal zekâlarının örgütsel bağlılıklarına etkisinde özyeterlilik algılarının aracı rolü vardır.

\section{ARASTIRMA}

\subsection{Araştırmanın Amacı ve Kapsamı}

Araştırmanın temel amacı Y Kuşağı bilgi çalışanlarının duygusal zekâ seviyeleri, öz-yeterlilik algıları ve örgütsel bağlılıklarının düzeyini ve bu değişkenlerin birbirleri ile olan ilişkilerini inceleyerek, öz-yeterlilik algısının, duygusal zekâ ile örgütsel bağlılık ilişkisi üzerindeki aracılık rolünü analiz etmektir. Ayrıca araştırmada Y Kuşağı bilgi çalışanlarının cinsiyet ve aynı işte çalışma sürelerine göre, bu değişkenlerin farklılık gösterip göstermediği de incelenmiştir.

\subsection{Araştırmanın Modeli}

Araştırmada önerilen hipotezlere göre tasarlanmış araştırma modeli Şekil 1'de belirtildiği şekildedir.

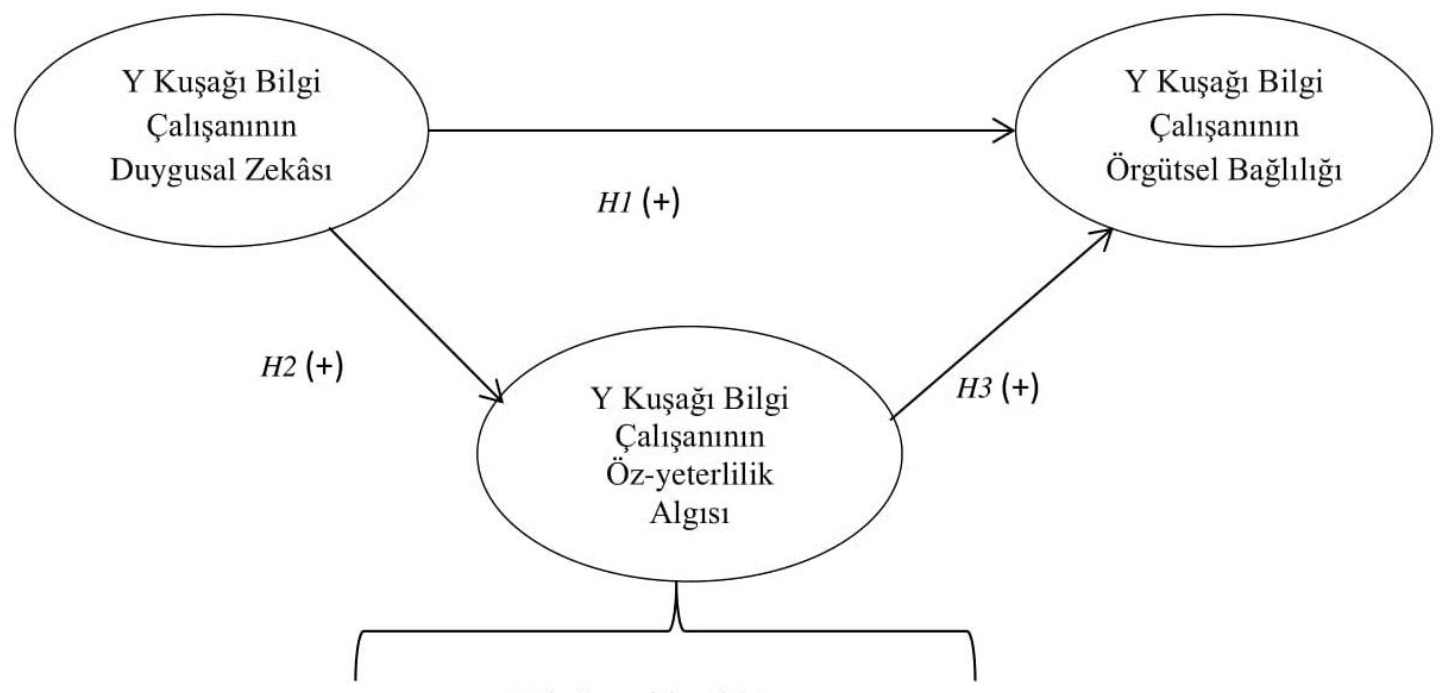

H4: Aracılık Etkisi

Şekil 1: Y Kuşağı Bilgi Çalışanlarının Duygusal Zekâsı ve Örgütsel Bağlılığı İlişkisinde ÖzYeterlilik Algısının Aracı Rolü 


\subsection{Araştırmanin Yöntemi}

Araştırma neden-sonuç ilişkisine bağlı olarak tasarlanmıştır. Araştırmada veri toplama tekniği olarak anket kullanılmıştır. Araştırmada toplanan veriler yapısal eşitlik modellemesi ile analiz edilmiştir. Aracıllk etkisinin testi için ise Baron ve Kenny (1986) yöntemi izlenmiştir.

\subsection{Katilimcilar}

Araştırmanın amacına hizmet edebilmek amacıyla çalışmada bilişim sektörü seçilmiştir. Özellikle bilişim sektörünün seçilmesinin sebebi bu sektörde çalışanların eğitim düzeylerinin yüksek olması ve bilgi çalışanı tanımının altında değerlendirilmesidir. Çalışmada evren seçimi olarak bilişim sektörünü temsil etmek amaciyla Ankara ilinde yer alan Hacettepe, Bilkent ve Gazi Üniversitesi'nin teknoparklarında faaliyet gösteren enformasyon ve iletişim teknolojileri ile elektronik gibi alanlarda ARGE faaliyetlerinde bulunan toplam 37 teknoloji şirketindeki çalışanlar seçilmiştir. Toplam 591 kişiden oluşan örneklemin katılımcılarının tümü üst düzey eğitimli, teknolojiyi etkili bir şekilde kullanabilen ve 1980 ile 1999 arasında doğmuş olan Y Kuşağına dahil kişilerdir. Anket dönüş oranı \%76 olarak tespit edilmiştir.

\section{5. Ölçüm Araçlart}

Anket iki bölümden oluşmaktadır. İlk bölümde Y Kuşağı bilgi çalışanlarının demografik özelliklerine ilişkin sorular yer almaktadır. Anketin ikinci bölümünde ise duygusal zekâ, öz-yeterlilik algısı ve örgütsel bağlılık ile ilgili sorular bulunmaktadır. Araştırmada ölçüm araçları demografik değişkenler dışında, 5'li Likert ölçeği ile değerlendirilmiştir (1=Kesinlikle katılmıorum, 5=Kesinlikle kat1liyorum).

3.5.1. Demografik Değişkenler. Anketin ilk bölümü demografik değişkenler ile ilgili soruları kapsamaktadır. Çalışanlara yaş, cinsiyet, eğitim ve aynı iş yerinde çalışma süreleri sorulmuştur.

3.5.2. Duygusal Zeka Ölçeği. Çalışanların duygusal zekâsını ölçmek için Wong ve Law (2002) tarafından geliştirilen duygusal zekâ ölçeği kullanılmıştır. Araştırmada, duygusal zekânın her boyutu (özbilinç, empati, duygu kullanımı, duygu yönetimi) için 4 sorunun kullanıldığı, toplam 16 değerlendirme sorusundan (Örn: Arkadaşlarımın duygularını gösterdikleri davranışlardan anlarım) oluşan tek bir ölçüm birimi kullanılmıştır. Ölçeğin Türkçe uyarlaması Güleryüz, Güney, Aydın ve Aşan (2008) tarafından yapılmıştır.

3.5.3. Öz-yeterlilik Ölçeği. Çalışanların özyeterliliği Schwarzer ve Jerusalem (1995) tarafından geliştirilen ve Türkçe uyarlaması Yeşilay, Schwarzer ve Jerusalem (1996) tarafindan yapılan ölçek ile değerlendirilmiştir. Öz-yeterlilik ölçeği toplam 10 maddeden (Örn: Beklenmedik durumlarda nasıl davranmam gerektiğini her zaman bilirim) oluşmaktadır. Ölçeğin 23 ülkede yapılan çalışmalarda güvenilirlik katsayısı ( $\alpha) 0.76$ ile 0.90 arasında elde edilmiştir.

3.5.4. Örgütsel Bağlılık Ölçeği. Çalışanların örgütsel bağlılığını ölçmede Mowday ve diğerleri (1979) tarafindan geliştirilen ve Türkçe uyarlaması Gürbüz (2011) tarafindan yapılan ölçekten (Örn: Bugün yeniden işe girecek olsam yine bu işletmede çalışmayı tercih ederim) yararlanılmıştır. Örgütsel bağlılık ölçeğinin orijinal versiyonu toplam 9 ifadeden oluşmaktadır. Ancak Türkçe uyarlaması sırasında Gürbüz (2011) tarafindan yapılan ölçeğin geçerlik ve güvenilirlik analizleri neticesinde orijinal versiyondaki iki madde zayıf psikometrik özelliklerinden dolayı ölçekten çıkarılmıştır.

\subsection{Geçerlilik ve Güvenilirlik Analizleri}

Araştırmada kullanılan ölçeklerin geçerliliğini test etmek için AMOS 16.0 programı ile doğrulayıcı faktör analizi yapılmıştır. Duygusal zekâ için analiz edilen tek faktörlü model, duygusal zekânın tüm boyutlarının (özbilinç, empati, duygu kullanımı, duygu yönetimi) birleşimiyle tek bir duygusal zekâ seviyesinin geçerli olduğunu göstermektedir. Benzer şekilde, hem öz-yeterlilik algısının, hem de örgütsel bağlılığın uygulananan analiz neticesinde tek faktör altında değerlendirildikleri tespit edilmiştir. Alanyazında genel kabul görmüş kriterlere göre CMIN/DF değerinin 3'ten küçük, GFI, CFI ve TLI değerlerinin 0.90'dan büyük, RMSEA değerinin ise 0.08 'den küçük olması

Tablo 1: Ölçeklerin Doğrulayıcı Faktör Analizi Sonuçları

\begin{tabular}{lccccc}
\hline Ölçek/Model & $\mathbf{x}^{\mathbf{2}} / \boldsymbol{d} \boldsymbol{f}$ & GFI & CFI & TLI & RMSEA \\
\hline Duygusal Zekâ (Tek boyutlu) & 2.42 & 0.92 & 0.91 & 0.93 & 0.07 \\
\hline Öz-yeterlilik (Tek boyutlu) & 1.94 & 0.94 & 0.97 & 0.96 & 0.05 \\
\hline Örgütsel Bağlılık (Tek boyutlu) & 2.13 & 0.93 & 0.92 & 0.94 & 0.06 \\
\hline$* p<0.01$ & & & & &
\end{tabular}


gerekmektedir (Hair, Black, Babin, Anderson \& Tatham, 2006). Doğrulayıcı faktör analizi bulguları, Tablo 1'den de anlaşıldığı gibi duygusal zekâ ölçeğinde tek faktörlü, öz-yeterlilik ölçeğinde tek faktörlü ve örgütsel bağl1lık ölçeğinde tek faktörlü modellerin en iyi uyumu verdiğini ortaya çıkarmıştır.

Tablo 2 ise güvenilirlik analizleri için ölçeklerin iç tutarlılığını belirlemekte kullanılan Cronbach Alpha ( $\alpha)$ katsayılarını göstermektedir.

Görüldüğü gibi ölçeklerin güvenilirliklerinin istenen seviyelerde (0.70 ve üzeri) (Nunnally, 1978) olduğu tespit edilmiştir. Dolayısıyla araştırmada kullanılan ölçeklerin Y Kuşağı bilgi çalışanları örneklemi için geçerli ve güvenilir olduğu tespit edilmiştir.

\section{BULGULAR}

\subsection{Demografik Özellikler}

Tablo 3'de katılımcıların demografik özellikleri gösterilmektedir. Daha önceden belirtildiği üzere tüm katılımcılar 1980 ile 1999 yılları arasında doğmuştur.

\subsection{Korelasyon Analizleri}

Tablo 4 değişkenlere ait ortalamaları, standart sapmaları ve korelasyonları göstermektedir.

Tablo 4'de görüldüğü gibi Y Kuşaği bilgi çalışanlarının örgütsel bağlılıkları, hem duygusal zekâları ile olumlu yönde ve anlamlı $(\mathrm{r}=0.26 ; p<$ 0.01 ), hem de öz-yeterlilik algıları ile olumlu yönde ve anlamlı $(\mathrm{r}=0.68 ; p<0.01)$ bir ilişkiye sahiptir. Y Kuşağı bilgi çalışanlarının duygusal zekâlarının ve öz-yeterlilik algılarının da olumlu ve anlamlı bir ilişkiye sahip olduğu bulunmuştur $(\mathrm{r}=0.28$; $p<$ $0.01)$.

\subsection{Yapısal Eşitlik Modellemesi ile Aracılık Testi}

Y Kuşağı bilgi çalışanlarının duygusal zekâlarının örgütsel bağlılıklarına etkisinde öz-yeterlilik algılarının aracılık rolü olup olmadığı iki ayrı yol analizi ile incelenmiştir. Oluşturulan yapısal yol analizi modelleri AMOS 16.0 yazılımı kullanılarak test edilmiştir. Aracılık analizi sonuçları Şekil 2'de gösterilmektedir. (Bkz. Şekil 2)

Aracılık etkisini incelerken Baron ve Kenny'nin (1986)'nin aracılık etkisi yöntemine göre, Y Kuşağı bilgi çalışanları örneklemi için, dört koşulun gerçekleşmesi gerekmektedir. Birinci koşulda, yordayıcı değişkenin (duygusal zekâ), yordanan

Tablo 2: Ölçeklerin Güvenilirlik Analizi Sonuçları

\begin{tabular}{lcc}
\hline Ölçekler & Madde Sayısı & Güvenilirlik \\
\hline Duygusal Zekâ & 16 & 0.78 \\
\hline Öz-yeterlilik & 10 & 0.82 \\
\hline Örgütsel bağlılık & 7 & 0.76 \\
\hline
\end{tabular}

Tablo 3: Katılımcıların Demografik Özellikleri

\begin{tabular}{|c|c|c|c|}
\hline \multicolumn{2}{|c|}{ Değişkenler } & $N=591$ & $\%$ \\
\hline \multirow{2}{*}{ Cinsiyet } & Kadın & 272 & 46 \\
\hline & Erkek & 319 & 54 \\
\hline \multirow{3}{*}{ Eğitim } & Üniversite & 446 & 75 \\
\hline & Yüksek Lisans & 128 & 22 \\
\hline & Doktora & 17 & 3 \\
\hline \multirow{2}{*}{$\begin{array}{l}\text { Aynı iş yerinde çalışma } \\
\text { süresi }\end{array}$} & $1-5$ y1l & 332 & 56.2 \\
\hline & 6 yil ve üzeri & 259 & 43.8 \\
\hline
\end{tabular}

Tablo 4: Değişkenlere ait Ortalama, Standart Sapma ve Korelasyon Katsayıları

\begin{tabular}{lccccc}
\hline Değişkenler & Ort. & SS & $\mathbf{1}$ & $\mathbf{2}$ & $\mathbf{3}$ \\
\hline 1. Duygusal Zekâ & 4.12 & 0.66 & --- & & \\
\hline 2. Öz-yeterlilik & 4.05 & 0.54 & $.28^{* *}$ & ---- & \\
\hline 3.Örgütsel & 4.17 & 0.59 & $.26^{* *}$ & $.68^{* *}$ & --- \\
Bağlılık & & & & & \\
\hline
\end{tabular}

$* * p<0.01$, Ort. =Ortalama, S.S.= Standart Sapma. 


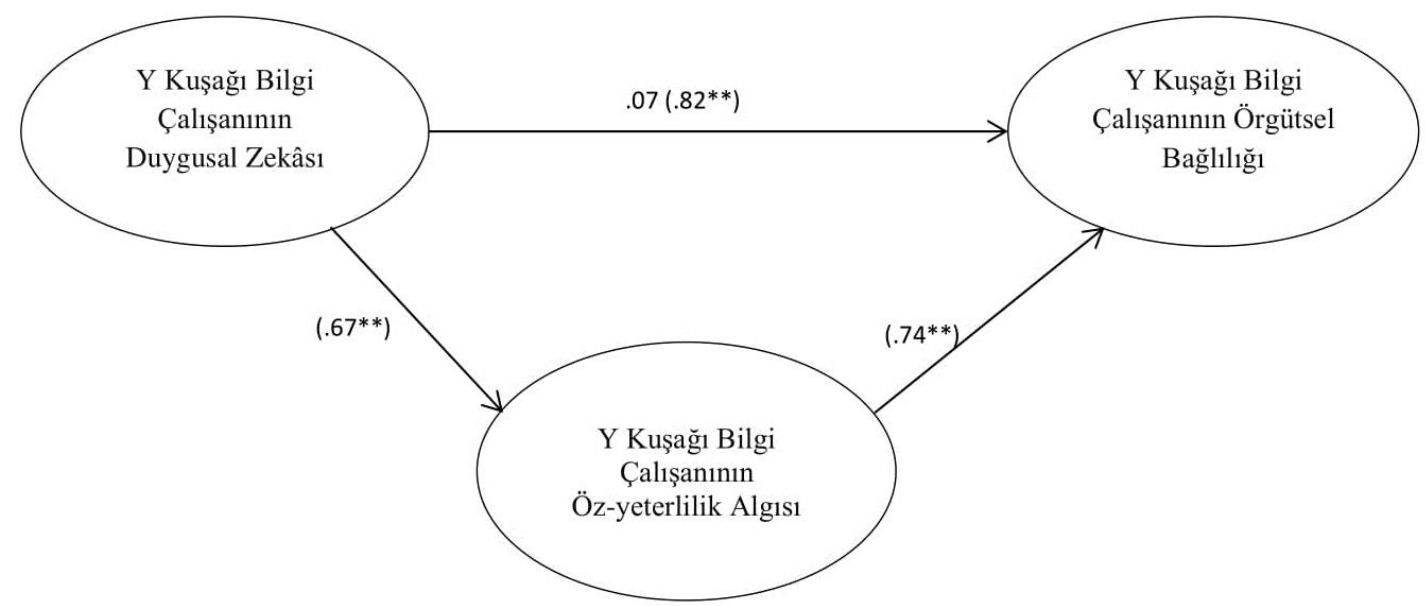

Şekil 2: Yapısal Eşitlik Modellemesi ile Aracılık Analizi, $* * p<0.01$

değişken (örgütsel bağlllık) üzerinde anlamlı etkisi olmalıdır. İkinci koşulda, yordayıcı değişkenin (duygusal zekâ), aracı değişken (öz-yeterlilik algısı) üzerinde anlamlı etkisi bulunmalıdır. Üçüncü koşulda, aracı değişkenin (öz-yeterlilik algısı), yordanan değişken (örgütsel bağll1ık) üzerinde anlamlı bir etkisi olmalıdır. Dördüncü koşulda ise hem yordayıcı (duygusal zekâ), hem de aracı değişkenin (öz-yeterlilik algısı), bağımsız değişken olarak yordanan (örgütsel bağl1lık) üzerindeki etkileri hesaplanmaktadır. $\mathrm{Bu}$ durumda yordayıcı değişkenin (duygusal zekâ), yordanan değişken (örgütsel bağlllık) üzerindeki etkisinin aracı değişken (öz-yeterlilik algısı) dahil edildiğinde anlamsızlaşması tam aracılılık, azalması ise kısmi aracılık olarak nitelendirilir.

Kurulan birinci model içinde duygusal zekânın örgütsel bağll1ık üzerindeki etkisi test edilmiştir. Elde edilen regresyon katsayıları her bir yol için parantez içerisinde verilmiştir. Birinci model incelendiğinde $\mathrm{Y}$ Kuşağı bilgi çalışanlarının duygusal zekâlarının örgütsel bağll1ıkları üzerinde olumlu ve anlamlı etkisi olduğu saptanmıştır $(\beta=$ $0.82, p<0.01$ ). Dolayisiyla Hipotez 1 kabul edilmiştir. Birinci modelde elde edilen değerler uyum indekslerine uygun olarak bulunmuştur $\left(\left[\mathrm{x}^{2}\right.\right.$ $(d f=192)=435.84 ; \mathrm{GFI}=0.93 ; \mathrm{CFI}=0.95 ; \mathrm{TLI}=$ $0.92 ;$ RMSEA $=0.05]$ ).

İkinci modelde öz-yeterlilik aracı değişken olarak modele dahil edilmiştir. Model incelendiğinde $\mathrm{Y}$ Kuşağı bilgi çalışanlarının duygusal zekâlarının özyeterlilik algıları üzerinde olumlu ve anlamlı etkisi olduğu görülmektedir $(\beta=0.67, p<0.01)$. $\mathrm{Bu}$ durumda Hipotez 2 kabul edilmiştir. Ayrıca $Y$ Kuşağı bilgi çalışanlarının öz-yeterlilik algılarının örgütsel bağll1ıkları üzerinde olumlu ve anlamlı etkisi olduğu tespit edilmiştir $(\beta=0.74, p<0.01)$. Dolayısıyla Hipotez 3 kabul edilmiştir. Görüldüğü gibi, Baron ve Kenny'nin üç koşulu da sağlanmış durumdadır. Öz-yeterlilik modele dahil edildiğinde ise duygusal zekânın örgütsel bağlılık üzerindeki etkisi (standardize beta $=.07 ; p>.05$ ) anlamsızlaşmaktadır. Bu durumda dördünce koşul da gerçekleşmiş olmaktadır. Dolayısıyla, Y Kuşağı bilgi çalışanlarının duygusal zekâlarının örgütsel bağlılıklarına olan etkisinde, öz-yeterlilik algıları tam aracı rolündedir. Dolayısıyla Hipotez 4 kabul edilmiştir. İkinci modelin uyum indeksleri kabul edilir sınırlar içinde bulunmuştur $\left(\left[\mathrm{x}^{2}(d f=197)=\right.\right.$ 491.76; GFI $=0.92 ;$ CFI $=0.94 ;$ TLI $=0.91$; RMSEA $=0.07]$ ).

\subsection{Farklıllk Analizleri}

Uygulanan farkl1lik testleri (t testi ve ANOVA) neticesinde cinsiyet, eğitim ve aynı iş yerinde çalışma sürelerine göre $\mathrm{Y}$ Kuşağı bilgi çalışanlarının duygusal zekâları, öz-yeterlilik inançları ve örgütsel bağlılıkları anlamlı bir farklılık göstermemiştir $(p>0.05)$.

\section{SONUÇ, TARTIŞMA VE ÖNERILLER}

Bu çalışmada, duygusal zekânın örgütsel bağl1lık üzerindeki etkisi ve duygusal zekâ ile örgütsel bağlılık ilişkisinde öz-yeterliliğin aracılık rolü $\mathrm{Y}$ Kuşağı bilgi çalışanları örnekleminde incelenmiştir. Sonuçlarda, Y Kuşağı bilgi çalışanlarının duygusal zekâlarının örgütsel bağlılıklarını olumlu ve anlamlı bir şekilde etkilediği görülmüsşür. Duygusal zekâ kişinin özdenetim duygusuyla azim ve sebat içinde kendisini harekete geçirmesini sağlamaktadır (Goleman, 2014). Y Kuşağı çalışanı ekip odaklı, işinde anlam arayan, yeni bilgiler öğrenmek için firsat kollayan, yeni kavramları ve fikirleri hızla benimseyen, sosyal ilişkilerde başarılı, en eğitimli ve teknolojik olarak bilgili kuşak olarak nitelendirilmektedir (Eisner, 2005: 6). Araştırma 
bulguları, duygularını anlayabilen, özbilinç sahibi, çevresindeki kişilerle empati yeteneği sayesinde örgütte iyi ilişkiler kuran, duygularını zorlu ve problemli durumlarda kontrol altına alıp yönetebilen Y Kuşağı bilgi çalışanının iş yerinde daha verimli olduğuna, işini daha zevkle yaptığına ve çalıştığg örgüte kendisini daha bağlı olarak hissettiğine dikkat çekmektedir. Bu bulgu; Aghdasi ve diğerleri (2011), Naderi (2012) ile Nikolaou ve Tsaousis'in (2002) sonuçları ile uyumludur. Mayer, Caruso ve Salovey'in (2016: 3) de ifade etmiş olduğu gibi kişisel ve çevresel duyguların farkındalığ 1 ile duygu kullanımı ve yönetimi becerisi, olumsuz duygularla baş edebilme ve işe karşı daha hevesli olmaya neden olarak örgütsel bağlılığı arttırmaktadır.

Çalışmanın önemli sonuçlarından bir tanesi de Y Kuşağı bilgi çalışanlarının duygusal zekâlarının özyeterlilik algılarına olan olumlu etkisidir. Bu bulgu; Chan (2004), Fabio ve Palazzeschi (2008) ile Lee ve Song (2010)'un sonuçları ile tutarlıdır. Kişinin öncelikle kendi duygularını anlayabilmesini ve yönetibilmesini sağlayan duygusal zekâ, daha sonra başkalarının duygularını anlama, ilişkileri kontrol etme ve kişide özgüvenin gelişmesi olarak ortaya çıkar. Çevredeki kişilerle iyi ilişkiler kurabilmede sosyal farkındalığın ve özgüvenin rolü büyüktür (Salovey \& Mayer, 1990). Duygusal zekâ aynı zamanda kişinin daha iyimser olmasına yardımcı olur. İyimserlik, çalışma yaşamında yüksek hedeflere sahip olunmasında ve güçlükler karşısında sebatkar bir tavir sergilenmesinde etkendir. Dolayısıyla özgüvenli olmak, duygusal zekâ ve iyimserlik, Y Kuşağı bilgi çalışanının öz-yeterlilik algısını olumlu olarak etkileyecektir.

Çalışmanın diğer önemli bulgusu da Y Kuşağı bilgi çalışanlarının öz-yeterlilik algılarının örgütsel bağlılıklarına olan olumlu etkisidir. Bu bulgu; Ayık ve diğerleri (2015), Paglis ve Green (2002) ile Schyns ve Von Collani'nin (2002) sonuçları ile uyumludur. Öz-yeterlilik algısı yüksek olan kişiler zorlayıcı ve yenilikçi ortamlar seçer, engellerle daha kolay başa çıkabilir, hedeflerine bağlılıklarını sürdürür, çevresini araştırmasına veya yeni çevreler yaratmasına imkan veren davranışlar gösterir (Yılmaz, Köseoğlu, Gerçek \& Soran, 2004: 262). Örgütsel bağlılığın içerdiği öğeler arasında çalışanın zamanını faydalı ve yaratıcı işlerde kullanması, yeniliklere açı ve istekli olması, fazladan çaba göstermesi, beceri ve yeteneklerini geliştirmesi, işbirliği içinde çalışması ve güvenilir olması gibi faktörler bulunmaktadır (Sahertian \& Soetjipto, 2011: 49-50). Öz-yeterlilik algıs1 yüksek olan çalışanların hedeflerine bağlılıklarını sürdürmeleri, örgütsel bağlılığın, beceri ve yeteneklerin geliştirilmesi, zamanı faydalı ve yaratıcı işlerde kullanım ve fazladan çaba gösterme gibi öğeleri ile örtüşmektedir. Öz-yeterliliğin özelliklerinden olan engellerle karşılaşıldığında daha hızlı toparlanabilme, zorlayıcı ve yenilikçi ortamlar seçme, yeni çevreler yaratılmasına imkan veren davranışlar gösterme ise örgütsel bağlılığın yeniliklere karşı açık ve istekli olma davranış özelliği ile parallellik göstermektedir. Bu bağlamda, çalışanın sahip olduğu kapasitenin, yaptığı işteki başarının, güdülerinin ve özdüzenleme mekanizması gibi benlik sistemini oluşturan öğelerin bir bileşkesinden oluşan öz-yeterlilik algısı, çalışanın örgütsel bağlılığını olumlu olarak etkilemektedir. Y Kuşağı çalışanlarının öz-yeterlilik algıları işe adanmışlık düzeylerini de olumlu olarak etkilemektedir (Keleş, 2014: 95). Kendisini işine adayan Y kuşağı bilgi çalışanının doğal olarak örgütsel bağlılık düzeyi de yükselecektir.

Çalışmanın en önemli sonuçlarından bir tanesi Y Kuşağı bilgi çalışanlarının öz-yeterlilik algısının, duygusal zekâ ile örgütsel bağlılık arasındaki ilişkide aracılık etkisine sahip olmasıdır. Diğer bir deyişle, Y Kuşağı bilgi çalışanının duygusal zekâsının yüksek olması, öz-yeterlilik algısı hissetmesine neden olmakta, bu da çalışanın örgütüne daha çok bağlanmasını sağlamaktadır. Yönetilmesi zor olan Y Kuşağı; takım çalışmasına yatkınlık, çoklu görev, yeniliklere açıklık, teknoloji kullanımı gibi konularda kendisinden önceki kuşaklardan daha ileri düzeyde, ancak bağımsız olmalarından kaynaklanarak örgütsel bağlıllık hususunda önceki kuşaklardan daha geri düzeydedir (Twenge, 2007; Ng vd., 2010). Bu durum, örgütlerin özellikle Y Kuşağı çalışanlarının örgütsel bağlılıklarına önem vermeleri gerektiğini göstermektedir. $\mathrm{Bu}$ açıdan, çalışanları özellikle Y kuşağı bilgi çalışanlarından oluşan örgütlerin, öncelikle çalışanlarının duygusal zekâlarını arttırıcı eğitimler düzenlemesi önerilmektedir. Örgütlerin düzenleyeceği eğitimler, etkin iletişim becerileri kazanma, takım çalışmasına yatkınlık ve duyguların etkili bir şekilde nasıl yönetilebileceği gibi konularda çalışanları geliştirebilir. Bunun yanı sıra, öz-yeterliliği yüksek olan çalışanların daha yenilikçi hareket ettiklerinden ötürü, yöneticilerin yeniliklere açık bir bakış açısına sahip olmaları gerekmektedir. Y Kuşağı çalışanları esnek çalışma saatlerinde daha çok verimli oldukları için, çalışanın iş saatlerini günün koşullarına göre düzenleyebilmesine firsat veren esnek çalışma saati uygulaması yapılması, bu kuşak çalışanlarının örgütsel bağlılıkları üzerinde olumlu etkide bulunabilir. Bu tarz uygulamaların, Y Kuşağı çalışanlarının motivasyonu, kişisel refahı, performansı ve örgütlerin hedeflerine ulaşmadaki başarısı üzerinde olumlu etkilediği belirlenmiştir (Deloitte, 2017).

Çalışmada kullanılan kesitsel veri ile araştırmanın sadece Türkiye'de yapılması çalışmanın kısıtlarını 
oluşturmaktadır. Gelecekteki araştırmalarda boylamsal veri kullanılması ve alan araştırmasının farklı ülkelerdeki Y Kuşağı bilgi çalışanlarına da yapılarak bulguların karşılaştırılmasının, sonuçların genelleştirilmesi açısından alanyazına önemli katkıda bulunacağı düşünülmektedir.

\section{KAYNAKÇA}

Abraham, R. (1999). The impact of emotional dissonance on organizational commitment and intention to turnover. The Journal of Psychology, 133(4), 441455 .

Acar, F. (2002). Duygusal Zeka ve Liderlik. Sosyal Bilimler Enstitüsü Dergisi, 12, 53-68.

Agarwal, S. \& Mishra, P. C. (2016). Self Efficacy as Predictor of Organizational Commitment among Revenue Personnel. The International Journal of Indian Psychology, 3(4), 44-57.

Aghdasi, S., Kiamanesh, A. R. \& Ebrahim, A. N. (2011). Emotional Intelligence and organizational commitment: testing the mediatory role of occupational stress and job satisfaction. ProcediaSocial and Behavioral Sciences, 29, 1965-1976.

Ayık., A., Savaş M. \& Yücel, E. (2015). İlkokullarda görev yapan okul müdürlerinin genel öz yeterlik ile örgütsel bağlılık algıları arasındaki ilişkinin incelenmesi. Uşak Üniversitesi Sosyal Bilimler Dergisi, 22, 193-218.

Arslan, R., Dilek, E. \& Aydın, E. (2013). Duygusal Zeka Örgütsel Bağlılık Arasındaki İlişki: Sağlık Çalışanları Üzerinde Bir Araştırma. Uluslararası Alanya İsletme Fakültesi Dergisi, 5(3), 169-180.

Ashforth, B. E. \& Humphrey, R. H. (1995). Emotions in the workplace: A reappraisal. Human Relations, 48, 97-125.

Aydogmus C. (2016). How to Satisfy Generation Y? The Roles of Personality and Emotional Intelligence. International Review of Management and Business Research, 5, 1342-1358.

Aydogmus, C., Camgoz, S. M., Ergeneli, A. \& Ekmekci, O. T. (2018). Perceptions of Transformational Leadership and Job Satisfaction: The Roles of Personality Traits and Psychological Empowerment. Journal of Management and Organization, 24(1), 81107.

Baggerly, J. \& Osborn, D. (2006). School Counselor's Satisfaction and Commitment: Correlates and Predictors. Professional School Counseling, 9(3), 197-205.

Bandura, A. (1988). Self-efficacy conception of anxiety. Anxiety research, 1(2), 77-98.

Bandura, A. (1997). Self-efficacy: The exercise of control. NY: Freeman.

Bar-On, R. (2006). The Bar-On Model of EmotionalSocial Intelligence. Psicothema, 18, 13-25. 
Baron, R. M. \& Kenny, D. A. (1986). The moderatormediator variable distinction in social psychological research: Conceptual, strategic, and statistical considerations. Journal of Personality and Social Psychology, 51, 1173-1182.

Bayram, L. (2005). Yönetimde Yeni Bir Paradigma: Örgütsel Bağl1lık. Sayıştay Dergisi, 59, 125-139.

Baysal, A. C. \& Paksoy (1999). Mesleğe ve Örgüte Bağl1lığın Çok Yönlü İncelenmesinde Meyer-Allen Modeli. I. Ü. IŞletme Fakültesi Dergisi, 28(1), 7-15.

Behrstock-Sherratt, E. \& Coggshall, J. (2010). Realizing the Promise of Generation Y. Educational Leadership, 67(8), 28-34.

Brown, E. A., Thomas, N. J. \& Bosselman, R. H. (2015). Are they leaving or staying: A qualitative analysis of turnover issues for Generation $\mathrm{Y}$ hospitality employees with a hospitality education. International Journal of Hospitality Management, 46, 130-137.

Carmeli, A. (2003). The relationship between emotional intelligence and work attitudes, behaviour and outcomes: An examination among senior managers. Journal of Managerial Psychology, 18(8), 788- 813.

Chan, D. W. (2004). Perceived emotional intelligence and self-efficacy among Chinese secondary school teachers in Hong Kong. Personality and Individual Differences, 36(8), 1781-1795.

Chi, H., Yeh, H. \& Choum, S. M. (2013). The organizational commitment, personality traits and teaching efficacy of junior high school teachers: The meditating effect of job involvement. The Journal of Human Resource and Adult Learning, 9(2), 131-142.

Controls, J. (2010). Generation $Y$ and the workplace annual report 2010. London: Forrester.

Cooper, R.K. \& Sawaf, A. (1997). Executive EQ: Emotional Intelligence in Leadership and Organizations. New York: The Berkley Publishing Group.

Deloitte (2017). The 2017 Deloitte Millennial SurveyApprehensive Millennials: seeking stability and opportunities in an uncertain world, 1-33.

Drucker, P. F. (1999). Knowledge-Worker Productivity: The Biggest Challenge. California Management Review, 41(2), 79-94.

Eisner, S. P. (2005). Managing Generation Y. Advanced Management Journal, 4-15.

Ergeneli, A. (2006). Örgüt ve İnsan. Ankara: Hacettepe Üniversitesi Yayınları.

Fabio, A. D. \& Palazzeschi, L. (2008). Emotional intelligence and self-efficacy in a sample of Italian high school teachers. Social Behavior and
Personality: An International Journal,36(3), 315326.

Goleman, D. (1995). Emotional Intelligence, New York: Bantam.

Goleman, D. (2014). Duygusal Zeka (Neden IQ'dan Daha Önemlidir?) (38.Bask1). İstanbul: Varlık Yayınları.

Güleryüz, G., Güney, S., Aydın, E. M. \& Aşan, Ö. (2008). The mediating effect of job satisfaction between emotional intelligence and organisational commitment of nurses: A questionnaire survey. International Journal of Nursing Studies, 45(11), 1625-1635.

Gürbüz, S. (2011). Stratejik İnsan Kaynakları Yönetiminin Örgütsel Bağlllı̆̆a ve İş Tatminine Etkisi: İnsan Kaynakları Yöneticileri Üzerinde Bir Araştırma. Atatürk Üniversitesi Sosyal Bilimler Enstitüsü Dergisi, 15(2), 397-418.

Hair, J., Black, B., Babin, B., Anderson, R. \& Tatham, R. (2006). Multivariate Data Analysis (6th ed.). NJ: Prentice-Hall.

Heslin, P. A. \& Latham, G.P. (2004). The Effect of Upward Feedback on Managerial Behavior. Applied Psychology: An International Review, 53(1), 23-37.

Iqbal, A. (2010). An empirical assessment of demographic factors, organizational ranks and organizational commitment. International Journal of Business and Management, 5(3), 16-27.

Irshad, E. \& Naz, S. (2011). Job satisfaction, organizational commitment and personality traits: A relationship study. The Journal of Humanities and Social Sciences, 19(2), 37-60.

Karcıoğlu, F. \& Çelik, E. (2012). Örgütsel İletişimin Etkinliği Açısından Kurumsal Bloglar ve Birkaç Kurumsal Blogun İncelenmesi. Atatürk Üniversitesi İktisadi ve İdari Bilimler Dergisi, 23(3), 1-17.

Kaufhold, J. A. \& Johnson, L. R. (2005). The analysis of the emotional intelligence skills and potential problem areas of elementary educators. Education, 125(4), 615-626.

Keleş, S. (2014). Aile şirketlerinde Y Jenerasyonunun öz yeterlilik algısı ve işe adanmışlık ilişkisi. Süleyman Demirel Üniversitesi Vizyoner Dergisi, 5(11), 95-109.

Korkmaz, T. \& Arpac1, E. (2009). Relationship of organizational citizenship behavior with emotional intelligence. Procedia-Social and Behavioral Sciences, 1(1), 2432-2435.

Lee, K. H. \& Song, J. S. (2010). The effect of emotional intelligence on self-efficacy and job stress of nursesmediating role of self-efficacy. Journal of Korean Academy of Nursing Administration, 16(1), 17-25. 
Lowe, D., Levitt, K. J. \& Wilson, T. (2008). Solutions for retaining Generation Y employees in the workplace. Business Renaissance Quarterly, 3(3), 43-57.

Lower, J. (2008). Brace Yourself Here Comes Generation Y. Critical Care Nurse, 28(5), 80-84.

Martocchio, J. J. \& Judge, T. A. (1997). Relationship between conscientiousness and learning in employee training: Mediating influences of self-deception and self-efficacy. Journal of Applied Psychology, 82(5), 764-773.

Mayer, J. D., Caruso, D. R. \& Salovey, P. (2016). The ability model of emotional intelligence: Principles and updates. Emotion Review, 8, 1-11.

Meyer, J. P. \& Allen, N. J. (1991). A Three Component Conceptualization of Organizational Commitment. Human Resources Management Review, 1, 61-89.

Meyer, J. P., Stanley, D. J., Herscovitch, L. \& Topolnytsky, L. (2002). Affective, Continuance and Normative Commitment to the Organization: A Metaanalysis of Antecedents, Correlates, and Consequences. Journal of Vocational Behavior, 61(1), 20-52.

Mowday, R., Steers, R. \& Porter, L. (1979). The measurement of organizational commitment. Journal of Vocational Behavior, 14(2), 224-247.

Naderi A. N. (2012). Teachers: emotional intelligence, job satisfaction, and organizational commitment. Journal of Workplace Learning, 24(4), 256-269.

Ng, E. S., Schweitzer, L. \& Lyons, S. T. (2010). New generation, great expectations: A field study of the millennial generation. Journal of Business and Psychology, 25(2), 281-292.

Nikolaou, I. \& Tsaousis, I. (2002). Emotional intelligence in the workplace: Exploring its effects on occupational stress and organizational commitment. The International Journal of Organizational Analysis, 10(4), 327-342.

Nunnally, J. C. (1978) Psychometric Theory, NY: McGraw-Hill.

Paglis, L. L. \& Green, S. G. (2002). Leadership SelfEfficacy and Managers' Motivation for Leading Change. Journal of Organizational Behavior, 23, 215-235.

Patalano, C. (2008). A study of the relationship between generational group identification and organizational commitment: Generation X vs. Generation Y. Nova Southeastern University.

O'Boyle E. H., Humphrey, R. H., Pollack, J. M., Hawver, T. H. \& Story, P. A. (2011). The relation between emotional intelligence and job performance: A meta-analysis. Journal of Organizational Behavior, 32(5), 788-818.

O'reilly, C. \& Chatman, J. (1986). Organizational commitment and psychological attachment: The effects of compliance, identification, and internalization on prosocial behavior. Journal of Applied Psychology, 71(3), 492-499.

Özkaya, M. O., Kocakoç, İ. D. \& Karaa, E. (2006). Yöneticilerin örgütsel bağlılıkları ve demografik özellikleri arasındaki ilişkileri incelemeye yönelik bir alan çalışması. Yönetim ve Ekonomi: Celal Bayar Üniversitesi İktisadi ve İdari Bilimler Fakültesi Dergisi, 13(2), 77-96.

Sahertian, P. \& Soetjipto, B.E. (2011). Improving Employees' Organizational Commitment, SelfEfficacy, and Organizational Citizenship Behavior Through the Implementation of Task-Oriented and Relationship-Oriented Leadership Behavior. The Business Review, Cambridge, 17(2), 48-60.

Salas, E. \& Cannon-Bowers, J. A. (2001). The science of training: A decade of progress. Annual Review of Psychology, 52(1), 471-499.

Salovey, P. \& Mayer, J. D. (1990). Emotional intelligence: Imagination, cognition and personality. Oxford: Blackwell Publishers.

Schyns, B. \& Von Collani, G. (2002). A new occupational self-efficacy scale and its relation to personality constructs and organizational variables. European Journal of Work and Organizational Psychology, 11(2), 219-241.

Schwarzer, R. (1994). Optimism, vulnerability, and selfbeliefs as health-related cognitions: A systematic overview. Psychology and Health: An International Journal, 9, 161-180.

Schwarzer, R. \& Jerusalem, M. (1995). Generalized selfefficacy scale. Measures in health psychology: A user's portfolio. Causal and control beliefs, 1(1), 3537.

Sinha, S. P., Talwar, T. \& Rajpal, R. (2002). Correlational study of organizational commitment, self-efficacy and psychological barriers to technological change. Psychologia, 45(3), 176-183.

Staples, D. S., Hulland, J. S. \& Higgins, C. A. (1999). A self-efficacy theory explanation for the management of remote workers in virtual organizations. Organization Science, 10(6), 758-776.

Şenel, E., Adiloğulları, İ. \& Ulucan, H. (2014). Examination of emotional intelligence level, teacher's self-efficacy beliefs and general self-efficacy beliefs of teachers. Journal of Physical Education \& Sports Science, 8(2), 224-232. 
Testa, M. R. (2001). Organizational commitment, job satisfaction, and effort in the service environment. The Journal of Psychology, 135(2), 226-236.

Thorndike, E. L. (1920). Intelligence and its uses. Harper's Magazine, 140, 227-235.

Twenge, J. M. (2007). Generation Me: Why Today's Young Americans Are More Confident, Assertive, Entitled - and More Miserable Than Ever Before. NY: Free Press.

Uysal, İ. \& Kösemen, S. (2013). Öğretmen adaylarının genel öz-yeterlik inançlarının incelenmesi. Journal of Research in Education and Teaching, 2, 217-226.

Ünal-Keskin, G. \& Orgun, F. (2006). Öğrencilerin öz etkililik-yeterlilik düzeyleri ile başa çıma stratejilerinin incelenmesi. Anatolian Journal of Psychiatry, 7, 92-99.

Wong, C. S. \& Law, K. S. (2002). The effects of leader and follower emotional intelligence on performance and attitude: An exploratory study. The Leadership Quarterly, 13(3), 243-274.

Yeşilay, A., Schwarzer, R. \& Jerusalem M. (1996). Genelleştirilmiş $\quad \ddot{z} \quad$ Yetki Beklentisi. http://userpage.fu-berlin.de/ health/turk.htm. Erişim tarihi: 17.05.2018.

Y1lmaz, M., Köseoğlu, P., Gerçek, C. \& Soran, H. (2004). Yabanc1 dilde hazırlanan bir ögretmen öz yeterlik ölçeğinin Türkçeye uyarlanması. Hacettepe Üniversitesi Eğitim Fakültesi Dergisi, 27, 260-267. 